\title{
1
}

\section{Speaking of Transition}

You must have noticed that politics, business, and society (is that us?) are confronted with increasingly pressing questions about economic and social transition. Things have to change-we are increasingly starting to agree on that, but how? What needs to change? We believe that it concerns three closely related and complex challenges.

\subsection{The Triple Transition-Climate, Energy, and Circularity}

Firstly, there is the climate challenge, which is encapsulated by the Paris Agreement of 2015 (a global agreement on the reduction of climate change negotiated at the 2015 United Nations Climate Change ConferenceCOP21), in which it was agreed to limit global warming to a maximum of 2 degrees above the pre-industrial era. For the first time in history, governments, NGOs, and businesses collaboratively agreed to address the climate challenge. This has led to national and international actions following from a shared understanding of the urgency of the problem. Both the severity of the consequences and the limited time available to address climate change dictate the agenda. To achieve the set goal to limit a global temperature rise, a reduction of greenhouse gas emissions of $45-50 \%$ is needed by 2030 . By 2050 , industrial activities will need to show net zero emissions. In the 2018 Intergovernmental Panel on Climate Change (IPCC, 2018) report on the speed of 
global warming as a result of greenhouse gas emissions, the need for emission reduction is clearly proven.

The second challenge is directly in line with the climate challenge: the energy transition requires the switch from fossil energy sources (gas and oil) to sustainable energy sources (including solar and wind energy, hydrogen, and biogas). The Dutch national ambition is $16 \%$ renewable energy by 2023 , on the way to entirely eradicating fossil fuels by 2050. In the European arena, the ambition is to become a $\mathrm{CO}_{2}$-neutral continent by 2050 . There are a lot of complicated issues involved, so it will certainly not be achieved without a struggle. But continuing with an economy that is addicted to fossil fuels is no longer a viable proposition going forward. Changes must be made no matter how difficult they might be technically, socially, and economically.

The third challenge is the pursuit of a circular economy: an economy of closed material loops, based on a policy initiated by the second Rutte administration (the cabinet of the Dutch government from 2012 to 2017), but actually driven by EU policy. The ambition is to achieve a substantially reduced use of virgin materials: $50 \%$ by 2030 and $100 \%$ by 2050 . It is now widely recognized that the low-carbon agenda is fundamentally intertwined with a circular economy agenda-making scaling up the circular economy an imperative (De Wit et al., 2019; Material Economics, 2018). Whether that can be fully achieved remains to be seen. After all, we use a lot of materials such as meat, fuel, or heat. Moreover, a large percentage of (processed) raw materials is stored in buildings, roads, cars, and so on. All these items have different lifespans. The lifespan of a plastic bottle may be a few weeks, but a cycle tunnel or a block of flats will last for 30 if not 50 years-the materials used are effectively stored as stock. Circularizing as many raw materials, components, and products as possible therefore requires radically different ways of organizing.

These three challenges combined result in a call for radical and major changes in the configuration of our economies. The seriousness of this situation is clear from the protests of farmers, builders, and citizens (among others). Normally quiet squares across Europe-be it in Paris, Madrid, London, Berlin, The Hague-seem to have changed into tournament fields on which fierce confrontations take place, with banners and chanting slogans as the new weaponry. Although intentions to create change may be making themselves heard, some of this (verbal) campaigning aims at preserving and maintaining the existing order. Key figures such as the young Greta Thunberg and Malala are leading the movements respectively on fighting climate change or realizing emancipation and inclusivity. Although they are getting 
the message out, these counter voices have not as yet really challenged nor moved the economic and social status quo.

However, the three challenges outlined call for the reconsideration and redesign of systems. These new systems should be able to address not just one, but all three challenging questions simultaneously. And addressing these is by no means a silver bullet, because there are also other directly related issues, such as the pursuit of restoring biodiversity or promoting social inclusivity, as reflected in, among others, the EU Green Deal, the Circular Economy Action Plan (CEAP), and the Just Transition Mechanism. The nature and scope of the issues are such that it is correct to speak of not one but of three challenges, and at the same time: a triple transition. After all, it concerns a climate challenge, an energy transition and a structural reduction of the use of resources. The aim to work on this systematically with definite goals in mind entails answering several (extra) questions.

The transition to sustainability is [...] our search for a new social contract: a natural social contract, with a radically different view on the relationship between man and his environment. This is a transition from ego-consciousness to eco-consciousness. Society is increasingly asking for a social order and environment that is ecologically sound, economically supported, and socially connected. Patrick Huntjens, Social Innovations Lector in the Green Domain, InHolland University of Applied Sciences.

These three Dutch challenges correspond with the EU policies on climate change, energy transition, and circular economy. These policies will hopefully provide the framework for a stable transition for the coming ten years. If we have the courage, and knowing that we have to, we will drastically change many of our systems and associated institutions. We have reached the end of the life cycle of the fossil fuel age. The decade 2020-2030 may, therefore, enter the history books as the period of the Great Social Renovation or the Transition Decade. The United Nations (the UN) speaks of the Decade of Action. In public debates, and sometimes also in political ones, the conservation and restoration of biodiversity is often referred to as a separate fourth dimension, as a transition of its own. The current international biodiversity treaty—-the UN Convention on Biological Diversity (www.cbd.int)—agreed that the decline of biodiversity must be halved by 2020, that overfishing must be stopped, that agriculture and forestry must be sustainable, and that the amount of protected nature must have increased from 10 to $17 \%$ globally. Clearly this is urgent, and much must be done in this regard. One hundred and ninety countries are currently negotiating a new agreement. In this publication, we do not view this as a separate transition but as a central part of the 
climate change challenge. We hope that this choice will not offend anyone and certainly not harm nature, insects, birds, fish, chickens, and all other animals. At the very least this call for more biodiversity-and considering it an extra dimension or transition of its own-is often linked to a request for paying more attention to the social dimension of transitions. Sometimes it is even argued that this should also be viewed as a separate transition. Even though this is a very intriguing and challenging perspective, in this book we choose to see the social dimension as an integral interdependent part of the triple transition we highlight-Climate, Energy, and Circularity. We believe that this choice does not reduce the interests or importance of the biodiversity or social aspects of these transitions, but only expresses that these are both integral dimensions of these transitions.

\section{Example}

The Government of the Netherlands' National Climate Agreement and Climate Act

On 28 May 2019, the majority of the Dutch Senate approved a Climate Act (www.government.nl/topics/climate-change/climate-policy). For the first time, the climate objectives are now set in law. In addition, the law has a mechanism that ensures that the government also achieves its stated climate goals. The Climate Act sets three objectives: (1) a reduction of $49 \%$ (compared to 1990) of greenhouse gas emissions by 2030 , (2) a $95 \%$ reduction (compared to 1990) of greenhouse gas emissions by 2050 , and (3) $100 \%$ greenhouse gas neutral electricity by 2050. As part of the Climate Act, the Government of the Netherlands committed to presenting a National Climate Agreement setting out the measures that are needed to achieve the objectives of the Climate Act. In December 2019, the Netherlands presented a National Climate and Energy Plan to the European Commission, and from 2020 onwards, the fourth Thursday of October will be Climate Day in the Netherlands.

But the Netherlands is not an island. Transition frameworks are being developed continuously in Europe, and more specifically, in Brussels. For some people, the pace of progress at the EU level may not be fast enough, while others regard this as patronizing. The fact remains that we cannot move forward in (relatively small) Europe without common frameworks for the three transitions. Traditionally, programmes such as Horizon 2020 and the Mission Innovation framework underpinning Horizon Europe are a step in the right direction. The current European Commission, which took office after the 2019 European elections, gives specific priority to these transitions as is evident from the European Green Deal published in 2019 and the new Circular Economy Action Plan (CEAP 2.0) (2020). See also the European Climate Law being proposed by the European Commission to write into law 
the goal set out in the European Green Deal-for Europe's economy and society to become climate-neutral by 2050: ec.europa.eu/clima/policies/eu-cli mate-action/law_en. Time will tell what the impact of these EU interventions will be.

\section{Example}

A sustainable Europe is one that opens up opportunities, innovates, creates jobs, and offers a competitive edge to its industries. The circular economy is key for developing Europe's future economic model. I will propose a New Circular Economy Action Plan focusing on sustainable resource use, especially in resource-intensive and high-impact sectors such as textiles and construction. To help drive the change we need, I will put forward my plan for a futureready economy, our new industrial strategy. [...] We will be a world leader in the circular economy and clean technologies. We will work to decarbonize energy-intensive industries. Europe is an industrial economy, and for many parts of our Union the local manufacturer, plant or factory is the hub for our communities. This is why I believe that what is good for our planet must be good for our people, our regions, and our economy. Von der Leyen $(2019$, p. 7)

This is a sketch of the (large) national and European contexts within which citizens, companies, and governments must jointly find their way. These transitions will certainly not be without struggles. The fact remains that we live in organized societies and economies in which together we need to shape these transitions. In this book, we adopt the perspective that the crux of our economic activity consists of a series of transactions. Transactions are those actions in which two or more parties make an exchange, which is experienced as the creation of value. These may involve products, such as buying a loaf of bread at the local bakery, or services, such as having your hair cut and paying the hairdresser. When you see it this way, our daily economic and social actions consist of a continuous process of large and small transactions throughout each and every day.

\section{Example}

Brussels is going to invest hundreds of billions of euros to make Europe the first climate-neutral continent. Among other things, two billion trees must be planted and one million charging points for electric cars installed. The design plan for the Green Deal stands out for its comprehensive nature. Putting up some solar panels and windmills here and there is considered totally inadequate. With these ambitious plans, Europe must become the first climate-neutral continent in the world. (Peeperkorn, 2019) 


\subsection{A New Model for Organizing Multiple Value Creation}

The deliberate designing and organizing of transactions and the value they create form the basis for the development of every business model. A central point of departure in this book is working on new forms of value creation. A business model shows how value creation is achieved and the resulting transactions. Transactions are those actions in which two or more parties make an exchange, which is experienced as the creation of value.

The Business Model Template (BMT) presented here is aligned with a long tradition of instruments or tools for modelling business or value propositions, and this is reflected in the attention this is given in various chapters (see Chapter 2-Business Modelling, Chapter 8-Strategy, and Chapter 12Value(s) Creation). Such instruments help users to contemplate and create a business model. The BMT, however, distinguishes itself by providing a system to enable users to develop a sustainable business model based on multiple value creation. But ultimately what happens in the template is up to the users themselves. After all, a template by itself is an empty thing. It prescribes the form, consisting of stages and building blocks. The user(s) themselves must develop the content in a clear, logical, and coherent fashion, and connect it to a value proposition accordingly. The challenge is creating an infrastructure that enables users to come up with a concept that organizes multiple value creation in a step-by-step manner: this is the gap that the BMT seeks to address.

Humankind is depleting nature at an unprecedented speed when it comes to resources as well as ecosystems. Major transformations are needed to prevent this. If you are serious about the transformations that we are facing, you must also question economic growth at all costs (Kalse, 2019).

The concept of multiple value creation means working on more than one value simultaneously. Or to put it more precisely, it always involves creating more than just financial value. For some, this means promoting biodiversity, or keeping materials in productive use in the economy, or restorative entrepreneurship-which refers to entrepreneurial activities aimed at the restoration of ecological and social systems. And to make it even more complicated, it is not a matter of either/or but rather of and-and-and. So the aim of multiple value creation is to develop solutions which address enhancing biodiversity, stimulate social inclusivity and work on the idea of restorative entrepreneurship (see Fig. 5.1, Chapter 5.2). We will return to this in detail in Chapter 5-The Proposition. 


\section{Important}

Three guiding principles

In light of the triple transition challenges and the different approaches in modelling the changing nature of value creation, three guiding principles play an important role: (1) being more sustainable (eco-efficiency), (2) designing and organizing closed loops with the aim of creating circularity, and (3) deliberately recreating the social fabric that underpins inclusivity. Together they provide the stepping stones for a new role of business models. Each of these principles is closely linked to the UN Sustainable Development Goals (SDGs) (see also Appendix D).

Being more sustainable means systematically reducing the use of resources and energy as well as reducing harmful side-effects such as pollution, destruction, and exhaustion. This applies to both the production of goods and their uses. This can be done by searching for new resources, using sustainably generated energy, recycling, and so on. This will increase the sustainability of existing processes and practices. Being more sustainable, however, does not question the underlying linear system; instead, the focus is on reducing and mitigating adverse effects. This debate has its origins in publications such as Silent Spring (Carson, 1962) or The Limits to Growth of the Club of Rome (Meadows et al., 1972). The arrival of the Our Common Future report by Gro Harlem Brundtland (WCED, 1987) gave a real boost to the debate. Since then, various institutions, such as the UN IPCC and the Resilience Institute in Sweden, have continuously and emphatically measured and visualized the degradation of our natural environment, while a wide range of platforms have advocated the urgency to take action. The urgency is now so highas evidenced by melting polar caps, temperature rise, extreme drought, and resulting forest fires - that radical and collective action is urgently needed.

Circularity involves the organization of value retention of resources, semifinished products, and products in loops, which requires a differently structured economic system. One of the key origins of the circular economy is generally attributed to Walter Stahel from Switzerland, who wrote a report for the EU in the late 1970s called The potential for substituting manpower for energy (Stahel \& Reday, 1977) and referred to it as The Performance Economy. Circularity also has antecedents in the field of Industrial Ecology and is related to ideas like Cradle to Cradle (McDonough \& Braungart, 2002), and the Blue Economy (Pauli, 2017). For a long time, these ideas were operating in isolation, until integrated and mainstreamed by the Ellen McArthur Foundation (see www.ellenmacarthurfoundation.org) who picked up the idea in 2013 and brought this philosophy to the attention of business, politics, and the general 
public in every possible way. The essential idea is that a circular economy replaces the traditional linear take-make-waste model.

Even if consumers are generally willing to engage in a circular economy, actual engagement is rather low. Further efforts are needed to develop a comprehensive approach to foster sustainable lifestyles and consumption, keeping in mind the need for a fair and just transition. To guide consumers and public authorities towards sustainable choices, information requirements on products regarding reparability, durability, or availability of spare parts need to be made available. In addition, consumers' empowerment in a circular economy will benefit from an improved system to tackle green claims. Environmental Footprinting can be the methodology to substantiate these claims. European Union Circular Economy Action Plan (New Circular Economy Action Plan, 2020 ec.europa.eu/environment/circular-economy/pdf/new_circular_eco nomy_action_plan.pdf).

After all, circularity is not about more recycling, but rather it focuses on designing products for reuse, repair, and ultimately lifetime extension. This will result in new forms of high-quality reuse, conversion (converting waste into new basic products), and substitution (the replacement of, for example, mined resources with renewable resources). The twofold question is, however, to what extent we can (a) make the existing way of producing and consuming more sustainable (implying using fewer materials, and less energy and transport for example) and (b) which parts are suitable for circular organizing (for not everything is fit to be circularized). Many things are consumed (such as fuel, vegetables, or apple juice) and these do not come back in a form that is suitable for use in the same loop. Moreover, it is possible to organize loops that are not sustainable. After all, you can recycle paper several times, but every time you need more water, energy, and resources. Circularity therefore goes hand in hand with being sustainable, but what that means exactly and where the balance lies is not always clear. It is a matter of trial and error.

\section{Definition}

Towards a new definition of sustainable development

The pursuit of sustainable development is a process that follows the needs of people, society, and the environment in the present without compromising the ability of future generations to meet their own needs. That endeavour contains a continuous exploration to find a balance between the principles of being more sustainable, circular, and inclusive. Ultimately, this should lead to both a restorative and a regenerative society and economy. 
Inclusivity has the social aspects of value creation as the central focus. Here, the point of departure is creating societies and economies in which people get equal access to social, public, and private goods and services. This includes offering jobs to people who cannot easily gain access to the labour market and giving equal rights to civic initiatives that currently apply to companies. When we look at a transition towards a sustainable and circular economy, all kinds of directly connected qualitative and quantitative social and labour market issues arise. Claims related to the potential of scaling up circularity to lead to a substantial increase in the number of jobs do not seem to be aligned with the required competence developments, knowledge agendas, and related training programmes required to implement circularity. Moreover, inclusivity explicitly concerns access to social and economic opportunities for people who are marginalized because they have no job or have insufficient financial means.

Finally, inclusivity also needs to apply to nature and ecosystems whereby nature and related ecosystems get a permanent place in decision-making processes. Biodiversity and everything related to it is crucial as a basis for a liveable planet and a healthy economy. Our business activities of the last century and a half have done considerable damage to nature and ecosystems. The pace at which biodiversity has been reduced in recent decades is so high that the question of what business is doing to restore it should be part of every corporate strategy and supported by every municipal and governmental plan.

While the urgency to take action is increasing, there remains a substantial gap regarding the scale of action required to address the triple transition outlined. Research by the Netherlands Environmental Assessment Agency (Planbureau voor de Leefomgeving, 2019) and Circularity Gap (De Wit et al., 2019), for example, shows that while we are generally quite good at recycling, we can barely connect this to higher order circular strategies, let alone social inclusivity. Many consider the forthcoming decade (20202030) to be crucial in shaping this transition. But the question remains as to how we go from the existing (dominant) linear economy to a different economy-one which is more sustainable, circular, and embeds inclusivity at its core? That is not possible by prioritizing one guiding principle or one transition above another, but by aiming at multiple transitions simultaneously. We refer to this as an integral approach. This sounds good, but it also makes things exponentially complicated, while uncovering the interdependence of the partial challenges in the pursuit of multiple transitions. We are facing an unprecedented challenge, which must materialize in the existing 
institutional and organizational fabric of our society that is still fundamentally geared towards economic activity which prioritizes short-term profit and the linear use of resources and materials. This existing order is a principal obstacle to the much-needed triple transition required across the globe.

The climate and society are moving towards ever-greater extremes. Strong social contradictions that have arisen due to individual interests and beliefs being pushed to the extreme threaten the balance that we so desperately need. With the symbolic year 2020 ahead, solutions seem farther away than ever. Peter van Vliet, editor-in-chief Sustainable News, Consulted on 15 December 2019.

\subsection{Measuring Performance}

Many of our existing business models are developed from an organizationcentric perspective, based on a strategic route focused solely on the growth of turnover, market share, and the level of profit or loss. Consequently, working on multiple value creation (the simultaneous realization of multiple forms of values that are of a social, ecological, and economic nature) and value retention is not in the DNA of these business models.

Traditionally, the performance of organizations is assessed on financial criteria, namely whether the organization has made a profit or a loss. This is starting to change since organizations increasingly need to take sustainability into account when assessing profit and loss. As a result, the interpretation of financial indicators will change. In the BMT, we adopt the set of non-financial performance indicators that were formulated and approved by the EU in 2019 with a focus on the Significance of climate-related issues for the business model and the impact on strategy (European Commission, 2019, p. 16). The performance indicators used include Energy consumption or production from renewable and non-renewable sources, GHG emissions breakdown, energy efficiency targets, and renewable energy targets. These indicators can also be (partly) linked to the SDGs. Together, these seem to be the guiding frameworks for the coming decade, creating the basis for a (practical) set of financial and non-financial indicators that provide insight into the integral performance of an organization. See the International Integrated Reporting Council (IIRC: www.integratedreporting.org) for an example of how these frameworks are used to report on these performances. For an overview of indicators entertained in the BMT, see Chapter 11. 


\section{Important}

The BMT helps enterprising people and their partners to establish a successful and future-proof value proposition that contributes to solving social and ecological issues and results in multiple forms of value creation.

For business models that are intentionally designed to give form and content to the triple transition tasks discussed earlier in this chapter, their value creation must be measured within a system that does justice to multiple value creation. From this perspective, our current accounting system needs to change because it virtually excludes indicators other than financial ones. Moreover, depreciation methods are aimed at reducing the value of assets to zero, while a central objective of the circular economy is value creation based on value retention. Current accounting methods do not promote sustainability in any way, in the sense of sparingly using resources and maintaining value. Moreover, our institutional frameworks concerning taxes, accounting, and other regulations legitimize the externalization of ecological and social costs - and this must change.

It is here against this background that we introduce a business model template and associated system that is based on the pursuit of multiple forms of value creation. The BMT is based on two previously published publications. The first is the book New Business Models; Working Together on Value Creation, which was published in 2014 (Jonker, 2014). This publication has provided several principles and concepts that together constitute the foundation for the basic community-based business model. The second publication is the workbook Organising for the Circular Economy, A workbook for developing Circular Business Models, published in the spring of 2018 (Jonker et al., 2018), which underpins the foundation for the circularity-based business model presented here. The Organising for the Circular Economy workbook can be downloaded free of charge in Dutch and English via www.circulairebu sinessmodellen.nl/product/werkboek-bmce. In the next section, we provide a brief overview of the BMT based on key questions, supplemented by several tips to enable the reader to get the most out of the BMT process.

\subsection{The Business Model Template}

The purpose here is to introduce you to the structure and style of this book and how the BMT is presented in the various chapters. The BMT system consists of three stages that are developed in ten building blocks. In Fig. 1.1, 


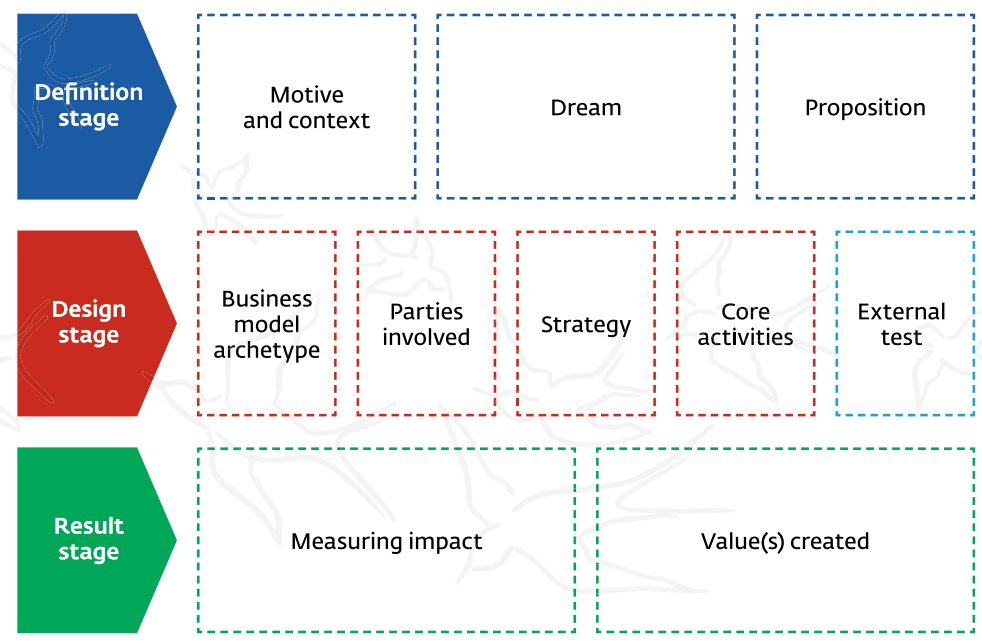

Fig. 1.1 Business Model Template

this is made evident in the building blocks being separated across three rows, with each row indicating a specific stage in the development process of a business model. The top row is the Definition Stage, the middle row is the Design Stage, and the bottom row is the Result Stage which together consist of ten building blocks. We will then walk through the template from top to bottom and from left to right.

Definition Stage: This stage consists of three building blocks: (1) Motive and Context, (2) Dream, and (3) Proposition. With these building blocks, you are trying to answer the following questions:

\section{Questions}

- What contribution will your business model make to sustainability challenges now and in the future?

- What do you think the gap in the market, or the gap in society is?

- What do you want to do and why?

- What is the problem, opportunity or challenge you want to address, and in what context?

- What is your internal drive and motivation?

- What dream goal do you want to achieve?

- Where are you going to make a real difference?

- Who are you going to do it for (who are your key stakeholders) and how will you sense-check whether they view the problem in the same way as you do? 
The result of the Definition Stage is an overview of the context, the problem statement, the ultimate end situation/goal that you have in mind, and finally a high-level but clear-cut formulation of your proposal to achieve that ultimate end goal.

\section{TIP}

While you are still in the Definition Stage, it is advisable to take a good look around at existing initiatives. For example, go and search on the internet around the challenge you are exploring and see what suggestions you find. Allow existing initiatives to inspire you but try also to keep an open mind regarding what you could do differently.

Design Stage: After you have crystallized what you are going to do in the Definition Stage, the logical next step is to work out how you are going to go about it-you are going to design your business model (Design Stage). Four of the five steps in this stage help you shape the organization of your business model as concretely as possible, with the fifth step focusing on enabling you to test your model externally. The first four steps in this stage include the following building blocks: (4) Business Model Archetype, (5) Parties, (6) Strategy, and (7) Core Activities. The fifth step in the Design Stage encompasses all of the preceding building blocks and subjects them to Building Block \#8-External Test.

With the building blocks in the Design Stage, you are trying to answer the following questions:

\section{Questions}

- How do you expect to achieve your dream/goal?

- Which strategy do you choose to realize your dream/goal?

- What activities will you undertake to realize this strategy?

- What type of business model will you use to create value?

- Who will you work with? With which stakeholders will you realize your value proposition?

- Have you tested your business model idea with potential users/partners/suppliers (have you done an external test, for example)?

- What do others think of your idea?

- Are you on the right track?

- Does your idea already exist in your context? What could you do better to make your offer unique? 
If you have not found an answer to one or more of these questions, then seek advice from a new person and see who can help you find the answer. It may be necessary to go back to the Definition Stage, to make your context and value proposition more specific.

\section{TIP}

During the Design Stage, we recommend copying the basic BMT structure onto a large sheet of paper and working out the different building blocks in this stage with Post-its ${ }^{\circledR}$, so that your choices can easily be changed or removed.

Result Stage: The third and final stage helps you to identify two essential building blocks of your business model: (9) the Impact that the business model has and (10) Value(s) Creation, in which it is made clear which values are being created.

\section{Questions}

- Which indicators will you choose?

- What are the positive and negative consequences of your business model, now and in the future?

- What value(s) are you creating and for whom?

- Which payment or transaction instruments will you be using?

- How do you shape transactions, and what do you exchange?

\section{TIP}

In the Result Stage, it is vital to be as concrete as possible. Do not be tempted to make big promises followed by a standard outcome-like the promise of a financially successful transaction model.

These last two building blocks provide insight beyond the conventional business model. In mainstream business modelling, often only the financial costs and benefits are considered. The impact that a business model has on its social, material, and ecological environment is not considered-regardless of it being an explicit question about the values that are being created. This is what differentiates the BMT from conventional business modelling: the BMT is one step ahead. 
We live in the aftermath of neo-liberalism which, with its externalities, has caused the biodiversity crisis and the ensuing climate crisis, and holds politics hostage worldwide. But an incredible thing is happening. Everywhere people are standing up to fight for the true values of our earth! Onwards to the coming decade of ecosystem restoration! Sanne Copijn on LinkedIn (Copijn, 2019)

In the next chapter, we will take a closer look at the history and background of business modelling. This is relevant because anyone who consults the literature in this field-even if only superficially_will find that the principles we address in the BMT are rarely, if ever, discussed, thus illustrating the gap which the BMT fills regarding the logic of multiple value creation.

\section{References}

Carson, R. (1962). Silent Spring. Houghton Mifflin.

Copijn, S. (2019). [LinkedIn post]. Retrieved on 4 November 2019 from: www.lin kedin.com/posts/sonne-copijn-8abb20_vroege-vogels-sonne-copijn-strijdt-tegenactivity-6596719605442457600-YJEk/.

De Wit, M., Verstraeten-Jochemsen, J., Hoogzaad, J., \& Kubbinga, B. (2019). Circularity Gap Report 2019: Closing the circularity gap in a 9\% world. Retrieved on 24 September 2020 from:docs.wixstatic.com/ugd/ad6e59_ba1e4d16c64f44f a94fbd8708eae8e34.pdf.

Dutch Government. (2019). The Government of the Netherlands National Climate Agreement and Climate Act 2019. Retrieved on 19 February 2020 from: www. government.nl/documents/reports/2019/06/28/climate-agreement.

Ellen MacArthur Foundation. (2012). Towards the circular economy Vol. 1: Economic and business rationale for an accelerated transition (p. 98). Ellen Mac Arthur Foundation. https://www.ellenmacarthurfoundation.org/assets/downloads/public ations/Ellen-MacArthur-Foundation-Towards-the-Circular-Economy-vol.1.pdf.

European Commission. (2013). Europe in a changing world-Inclusive, innovative and reflective societies. Retrieved on 24 September 2020 from: ec.europa.eu/pro grammes/horizon2020/en/h2020-section/europe-changing-world-inclusive-inn ovative-and-reflective-societies.

European Commission. (2019). Report on climate-related disclosures. Retrieved on 24 September 2020 from: ec.europa.eu/info/sites/info/files/business_economy_e uro/banking_and_finance/documents/190110-sustainable-finance-teg-report-cli mate-related-disclosures_en.pdf.

IPCC. (2018). Global warming of $1.5^{\circ} \mathrm{C}$ : An IPCC Special Report on the impacts of global warming of $1.5^{\circ} \mathrm{C}$ above pre-industrial levels and related global greenhouse gas emission pathways, in the context of strengthening the global response to the threat of climate change, sustainable development, and efforts to eradicate poverty. Intergovernmental Panel on Climate Change. http://www.ipcc.ch/report/sr15/. 
Jonker, J. (2014). New business models; Working together towards value creation. Academic Service.

Jonker, J., Stegeman, H., Faber, N., \& Kothman, T. H. (2018). Eén zwaluw belooft veel goeds - resultaten van het landelijke onderzoek 2016-2017 naar business modellen voor de circulaire economie. Stichting OCF 2.0.

Kalse, E. (2019). Afzien van economische groei, kunnen we dat wel? NRC Handelsblad. Retrieved 10 May 2019 from: www.nrc.nl/nieuws/2019/05/10/afzien-vangroei-kan-een-economie-dat-a3959860.

Material Economics. (2018). The circular economy: A powerful force for climate mitigation. Material Economics. https://materialeconomics.com/material-economicsthe-circular-economy.pdf?cms_fileid=340952bea9e68d9013461c92fbc23cae.

McDonough, W., \& Braungart, M. (2002). Cradle to cradle: Remaking the way we make things. North Point Press.

Meadows, D. H., Meadows, D. L., Randers, J., \& Behrens, W. W. (1972). The Limits to Growth. Universe Books.

Pauli, G. (2017). The Blue Economy 3.0: The marriage of science, innovation and entrepreneurship creates a new business model that transforms society. XLIBRIS.

Peeperkorn, M. (2019). Met deze ambitieuze plannen moet Europa het eerste klimaatneutrale continent ter wereld worden. Volkskrant. Retrieved 10 December 2019 from: www.volkskrant.nl/nieuws-achtergrond/met-deze-ambitieuze-pla nnen-moet-europa-het-eerste-klimaatneutrale-continent-ter-wereld-worden-bf2 $271 \mathrm{ac} /$ ?referer $=$.

Planbureau voor de Leefomgeving. (2019). Outline of the Circular Economy. The Hague: PBL Retrieved from: circulareconomy.europa.eu/platform/sites/default/ files/pbl-2019-outline-of-the-circular-economy-3633.pdf.

Stahel, W. R., \& Reday, G. (1977). The potential for substituting man-power for energy: Report to DG V for Social Affairs (76/13; Programme of Research and Actions on the Development of the Labour Market). Commission for European Communities.

Von der Leyen, U. (2019). A Union that strives for more: My agenda for Europe. Political Guidelines for the next European Commission 2019-2024. Commission for European Communities. Retrieved on 24 September 2020 from: ec.europa.eu/commission/sites/beta-political/files/political-guidelines-nextcommission_en.pdf.

WCED. (1987). Our Common Future. Oxford University Press. 
Open Access This chapter is licensed under the terms of the Creative Commons Attribution 4.0 International License (http://creativecommons.org/licenses/by/4.0/), which permits use, sharing, adaptation, distribution and reproduction in any medium or format, as long as you give appropriate credit to the original author(s) and the source, provide a link to the Creative Commons license and indicate if changes were made.

The images or other third party material in this chapter are included in the chapter's Creative Commons license, unless indicated otherwise in a credit line to the material. If material is not included in the chapter's Creative Commons license and your intended use is not permitted by statutory regulation or exceeds the permitted use, you will need to obtain permission directly from the copyright holder.

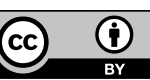

